\title{
Contributions to consolidate the new public governance: identifying dimensions of analysis
}

\author{
Breno Augusto Diniz Pereira ${ }^{1}$ \\ IVAN BECK CKAgNAZAROFF ${ }^{2}$ \\ ${ }^{1}$ Universidade Federal de SANTA Maria (UFSM) / Programa de Pós-Graduação em Gestão de Organizações Públicas e Programa \\ de Pós-Graduação em Administração Pública, Santa Maria - RS, Brazil \\ ${ }^{2}$ Universidade Federal de Minas Gerais (UFMG) / Departamento de Ciências Administrativas do Centro de Pós-Graduação e \\ PESQUISA EM ADMINISTRAÇÃo dA FACULDADE DE CIÊNCIAS ECONÔMICAS, BELO HORIZONTE - MG, BRAZIL
}

\begin{abstract}
The current demands from society to public administration requires understanding new public governance (NPG) as a management model, involving citizens in the public policy decision-making processes. Therefore, from a macro-perspective, information on NPG may contribute to developing strategies to meet citizens' demands, which is not a usual practice in existing public administration models. This work identifies dimensions of NPG analysis, filling a gap in the literature. The foundations for NPG analysis are deliberative democracy, co-production, and public value, and the dimensions are identified based on structure and processes. The study found that NPG uses tools from previous administration models, focusing on democratic and legitimacy principles. Finally, the research emphasizes the need for theoretical and empirical studies to understand NPG tools better, enabling a more inclusive public administration with more legitimate actions.
\end{abstract}

Keywords: New public governance. Public administration models. Democracy. Legitimacy.

\section{Contributions to consolidate the new public governance: identifying dimensions of analysis}

\section{Resumo}

Compreender a New Public Governance (NPG) como modelo de gestão vai ao encontro do atendimento às demandas atuais impostas pela sociedade às administrações públicas, em que há a necessidade de envolver os cidadãos no processo decisório das políticas públicas. Com isso, numa perspectiva macro, gerar informações sobre a evidenciação da NPG poderá contribuir para o desenvolvimento de estratégias que atendam às demandas que os cidadãos impõem à gestão, algo até então pouco efetivado pelos modelos existentes de administração pública. Dessa forma, este trabalho objetiva levantar dimensões para a análise da NPG, ainda carente na literatura. Conforme demonstrado, existem fundamentos para isso, entre eles: democracia deliberativa, coprodução e valor público. Por meio desses pressupostos, são analisadas dimensões sobre dois focos principais: estrutura e processos. Verificou-se que a NPG utiliza ferramentas dos modelos administrativos anteriores, mas busca sua ênfase dentro dos princípios democráticos e de legitimidade. Por fim, ressalta-se a necessidade de estudos teóricos e empíricos que possibilitem maior compreensão dessas ferramentas, permitindo uma administração pública mais inclusiva e com ações mais legítimas.

Palavras-chave: New Public Governance. Modelos de administração pública. Democracia. Legitimidade.

\section{Contribuciones a la consolidación de la Nueva Gobernanza Pública: identificación de las dimensiones para su análisis}

\section{Resumen}

La comprensión de la Nueva Gobernanza Pública (NGP) como modelo de gestión cumple con las demandas actuales impuestas por la sociedad a las administraciones públicas, donde es necesario involucrar a los ciudadanos en el proceso de toma de decisiones de las políticas públicas. Con esto, en una perspectiva macro, la generación de información sobre la divulgación de la NGP puede contribuir al desarrollo de estrategias para satisfacer las demandas que los ciudadanos imponen a la gestión, algo que hasta el momento no fue implementado de manera efectiva en los modelos de administración pública existentes. Así, este trabajo tiene como objetivo plantear dimensiones para el análisis de la NGP, que aún carece de literatura. Como se demostró, existen bases para el análisis de la NGP que son: democracia deliberativa, coproducción y valor público. Mediante estos supuestos, se analizan las dimensiones desde dos enfoques principales: estructura y procesos. Se verificó que la NGP utiliza herramientas de modelos administrativos anteriores, pero busca su énfasis dentro de los principios democráticos y de legitimidad. Finalmente, también se enfatiza la necesidad de estudios teóricos y empíricos que permitan una mayor comprensión de estas herramientas, permitiendo así una administración pública más inclusiva con acciones más legítimas.

Palabras clave: Nueva Gobernanza Pública. Modelos de administración pública. Democracia. Legitimidad. 


\section{INTRODUCTION}

Governance has become a fashionable word in the area of public administration. In academia or in practice, it is a "tool" for managers to implement public policies with greater effectiveness (Hufty, 2010). The goal of this work is to present a proposal to analyze governance considering the evolution of public administration paradigms in the face of a more citizen- oriented democracy.

It is understood that public governance is inspired by democratic theories which are concerned with greater participation in public spaces and government's need for efficiency and democratic legitimacy (Lynn \& Malinowska, 2018). In this way, public governance, or New Public Governance (NPG), as a model, and not a management tool applied to bureaucratic administration and New Public Management (NPM), can contribute to the consolidation of a more inclusive democracy, which desires political citizens and the expansion of the public sphere.

To Kissler and Heidemann (2006) and Paula (2005), public governance is associated with a change in socio-political, economicfinancial and institutional-administrative dimensions, because it points to the consolidation of co-produced processes and the co-management of social issues in public management, emphasizing active participation, joint action and the inclusion of citizens in the political community, as well as recognizing the excluded as citizens and generating public spaces for participation and social control. Public governance expresses a political desire to implement a democratic project which makes more articulation possible between the state and civil society, as well as the political will to construct public spaces which implement participation in an effective manner - and the expansion of politics to the extent that it considers the importance of civil society in its decisions - the fruit of expanded debate and deliberation - and in the formulation of public policies (Dagnino, Olivera \& Panfichi, 2006).

In this work, public governance is understood as referring to the relationship between those who govern and who are governed, associated with the co-production of development, but mainly the construction of a more inclusive democracy which enables the citizen to construct, coordinate and evaluate public policies. It refers, therefore to the governmental dimension, or in other words, a type of governmental institutional arrangement which, in articulating economic-financial, institutional-administrative and socio-political dimensions, establishes partnerships with civil society and the market through deliberative processes, and seeks innovative solutions to social problems.

\section{A BRIEF CONTEXTUALIZATION OF THINKING ON PUBLIC GOVERNANCE}

During the second half of the $20^{\text {th }}$ century, in the face of the intense rhythm of the capitalist system which assumed social and economic relationships, the bureaucratic public administration movement proved limited due to its blind obedience to norms which led to rigidity in practice. This led to state movements of greater flexibility and stimulated a change in the process to focus on results, presenting the first signs of a reform which would guide the transcription of the bureaucratic administration movement to managerial public management or New Public Management (NPM).

NPM represents a group of assumptions and values about how public organizations should be constituted, organized, managed, and, similar to private businesses, function (Diefenbach, 2009). In focusing on efficiency, control and management by results, NPM adopted a technocratic perspective based on a necessary independence between policy and public management, revisiting the public administration-policy dichotomy (Wiesel \& Modell, 2014).

According to R. B. Denhardt and J. V. Denhardt (2003) and Radnor, Osborne and Glennon (2016), however, NPM faces a series of problems. First, society has been profoundly transformed since the beginning of NPM in the 1980s; it has become more fragmented, and it is more and more difficult, if not impossible, for public organizations to respond in an isolated fashion to social needs. In this way, the state no longer acts as a single agent in the delivering of public services; on the contrary, it requires the collaboration of various actors to provide its services. As a consequence, it can no longer act as if its efficiency and its efficacy are in its hands alone. With great frequency, reforms such as NPM have concentrated only on internal efficiency, instead of focusing on efficiency in meeting the needs expressed by service users and citizens (Radnor et al., 2016). 
Secondly, in NPM the task of providing public services is conceived of as something to be realized by public service professionals in a location where the service user plays a very passive role in the process, as a "customer". R. B. Denhardt and J. V. Denhardt (2003) emphasize that public organizations are already involved in the expression of societal values and should concede a part of their decision-making power to members of society". To Carneiro and Menicucci (2011), society needs an active state, which means organizational tools and forms which engage in a dialogue with society and guarantee in an effective manner the resolution of its problems.

Finally, NPM has not been capable of responding to the challenges of practices oriented by knowledge and providing services in a digital economy. This is transforming not only the nature of the relationships between public organizations and service users, but also questions the valorization of the public as an indicator of the efficacy of public services, instead of internal measures of the efficiency of public services and governance processes which are necessary to negotiating an agreement about this efficacy (Brown \& Osborne, 2013).

Allied with this are a series of new transversal challenges for nation states - such as the expansion of preventive measures in terms of health care and improving public safety and employability - which have risen to prominence (Klijn \& Koppenjan, 2004). Problems associated with the migration of peoples, for example, frequently cannot be solved by the policies of a single country, because they depend on the articulation of a group of nations, as well as the apparatus of federal, state and municipal government bodies, in partnership with international organizations such as the United Nations and various other local social organizations working together.

These problems demonstrate the incapacity of the state in the application of NPM and the bureaucratic model associated with it to resolve complex problems which cannot be solved by the hierarchical structures of public administration. This strengthens the call for horizontal coordination through the interaction between public and private actors.

In this manner, it is perceived that public administration needs new initiatives or models for state action, removing the state from an exclusive role in meeting society's needs. The advance of these approaches has been treated by a current of public governance, which as one of its main characteristics, considers a plural state in which various interdependent actors contribute to providing public services, and is also pluralist in that various processes and actors influence the system of public policy decision making.

To Osborne (2006), public management contemplates more and more inter-organizational articulation, involving a group of actors which participates in the execution of public policies and the identification and conception of them, and which relies on the need for a systemic and process based vision, substituting the one-off, limited vision of social problems. NPG changes the institutional relations between the public sector and society, expanding the networks between organizations within and outside of the government in order to provide public services. The emergence of non-hierarchical relations inhibits formal command systems and requires the construction of ties based on confidence for informal relational contracts, respecting the expectations and abilities of both parties. The state becomes, finally, an organization of plural action, which demands changes in its form of action and the construction of methodologies to be used to understand its role in this new model within this new coordination system (Head \& Alford, 2015).

Peters and Pierre (1998) analyze that, while NPM is focused on results, NPG is more concerned with the processes of the structure. Moreover, they state that NPG, like any other model, is influenced by the political and cultural environment, and can be configured in distinct structures according to national contexts. NPM, on the other hand, maintains a certain neutrality in relation to the context in which it may be applied, presenting a group of principles and propositions which can be applied to any reality with no problems due to adaptation. While NPM revolves around intra-organizational processes, NPG revolves around inter-organizational actions.

In addition, NPG believes that participative and deliberative forms of democracy can collaborate to face complex problems of public administration, making it possible to expand the capacities of the state (Carneiro \& Menicucci, 2011). To accomplish this, the public organizations of the state should be permeated by the objective of responsiveness and public value and address public concerns, and these should be held above the interests of classes and social groups. This understanding makes studies of NPG reflect on issues associated with the management of change in complex systems, thus encompassing the broader social, political and ethical context which involves public administration. 


\section{Dimensions of the analysis of NPG}

The NPG model wants the state to work to reconcile the diverse interests concerned with a more efficient, responsive and democratic public administration. According to Osborne (2010) and Wiesel and Modell (2014), the principles of the bureaucratic model and NPM continue to exist and can be important tools to understanding the construction process of NPG.

To Bingham, Nabatchi and O'Leary (2005) and Sorrentino, Sicilia and Howlett (2018), NPG is a public administration model that is capable of reconciling interests in efficient and effective management, with a greater participation of democratic bases for the construction, management and implementation of public policies. In advanced societies, the inclusion of a plurality of actors, beyond the public sector, in governance processes is considered to be a practical way to approach problems which are more and more complex (Sorrentino, Marco \& Rossignoli, 2016). Thus, the engagement of citizens in the public service cycle reinvigorates the realization of public goals and is seen as an effective option for modern public administration. In other words, NPG exposes fundamental bases for the construction of public space, introducing new structures, new management processes, and a more inclusive democracy for deliberation on, and the construction of, public policies.

In this way, the basic fundamentals which make up the NPG model need to be emphasized, or in other words, the essential dimensions which distinguish it from other models of public administration. These dimensions, as we have seen in this work, may favor a larger form of citizenship and participation in decisions. Thus, one way to approach NPG requires the analysis of the following constructs: deliberative democracy, the public value of decisions, and the co-production of decisions.

\section{Deliberative democracy}

Habermas (1995), in elaborating the concept of deliberative democracy, is preoccupied with the way in which citizens rationally base the rules of the democratic game. They seek to create conditions to legitimize democracy where the discourse theory proposes an "ideal procedure of deliberation and decision making". To Faria (2000), this democratic procedure, in conjugating pragmatic considerations, commitments, and a discourse of self-understanding and justice, is based on the assumption that rational and just results will be obtained through a flow of relevant information which should be employed without hindrance.

The operationalization of this ideal deliberation and decision making procedure, or in other works, deliberative policies, depends, according to the discourse theory, on the institutionalization of procedures and the conditions of communication, as well as the interrelationship of institutionalized deliberative processes with informally constituted public opinions.

Bohman (1996, p. 183) notes, within this context, the issue of legitimacy. To him, the legitimacy of "a law is the result of a just and open participative process open to all citizens, which includes all the publicly accessible reasons of these people". The author does not presuppose a unanimous agreement between citizens and legislators on all laws, objectives or decisions, but rather continual cooperation despite the differences in the positions of a pluralist society. The constitution of consensus, in this version, will depend on participation in the public and legislative process, independent of disagreements on any particular decision reached in a deliberative manner. In participating in a just, inclusive and cooperative process, citizens will arrive rationally and publicly at a legitimate action (Faria, 2000).

To understand democratic legitimacy, therefore, we need to add a moral dimension: those that concede legitimacy should do this because they believe it is morally correct. To Dryzek (2010) and Sant'Anna, Alcântara, Pereira, Cappelle and Tonelli (2019), it is also necessary to add a dimension of freedom: those who concede legitimacy have to do so of their own free volition. Therefore, we need to add a dimension of competence: those who concede legitimacy should do so with full awareness of what they are being asked to accept. Thus, legitimacy does not just signify acceptance: it also refers to moral rectitude and competence in the process of acceptance.

\section{Public value}

NPG sees public value emerging from dialogue and deliberations which are broadly inclusive. In the understanding of Bozeman (2007), the public values of a society are those which provide normative consensus about: "(1) rights, benefits and prerogatives which citizens should (and should not) have; (2) citizens' responsibilities to society, the state, and between themselves; and (3) principles which governments and policies should be based on". 
To Alford and Hughes (2008) and Jørgensen and Bozeman (2007), public value can be produced by governmental organizations, private companies, non-profit or volunteer organizations, service users or various other entities. It is not who produces something that makes it a public value. On the contrary, it's a question of who consume it. As Moore (1995) explains, public value is the value collectively "consumed" by citizens and not individually by "customers". This involves more than public goods as defined by economists. At a minimum, it also includes solutions for "failures of the market" of various kinds, that is, situations in which market mechanisms do not maximize the individual well-being of citizens, such as negative externalities, natural monopolies, and imperfect information. At the same time, citizens can also value institutional arrangements which enable markets to operate and social orders to function, such as the state of law, the maintenance of order and mechanisms to protect the rights of property and the application of the law.

In the first place, a reason why citizens value these arrangements is because they benefit from them personally. However, in many cases they also value them for reasons that go beyond self-interest. They have goals or aspirations for society as a whole, based on social or normative commitments (Moore, 1995), such as justice, national pride, taking care of the environment, or concern about those in want or those who are vulnerable.

Secondly, what Bozeman (2007) calls a "failure of the market" occurs when neither the market nor the public sector can provide goods and services to achieve necessary public values. Public values to Bozeman (2007), can therefore be measured, even though there are divergencies over how they should be conceived of and measured (Bryson, Crosby \& Bloomberg, 2014). One implication is that analysts, citizens and policy formulators should concentrate on what are public values and the ways in which institutions and processes are necessary to establish agreements and achieve public values in practice (Davis \& West, 2009; Kalambokidis, 2014).

Moore (1995) argues that public managers should use what he calls the strategic triangle. The strategy should be (1) dedicated to achieving something of substantial value (that is, it should constitute a public value), (2) legitimate and politically sustainable, (3) operationally and administratively viable. Moore "equals managerial success in the public sector to founding and remodeling organizations in the public sector in a way that increases their value to the public in the short term and the long term", which requires restless imagination and seeks value.

To Moore (1995), just as to Bozeman (2007), public value generally refers to state objectives in the world which can be measured. Something that is being evaluated may be considered an inherent value or a means to something else. To sum up, the authors summarize the group of assumptions in which public organizational efficiency, responsibility, and justice, and justice within the context of democratic governance are primordial values.

\section{Co-production}

According to the understanding of Amamoto, Pereira and Alcântara (2020), co-production is a group of activities which features the participation of public agents and citizens who construct public policies and actions together, seeking the best delivery of services. Nabatchi, Sancino and Sicilia (2017) see co-production as necessary during times of austerity, while others see it as a way to redefine the roles of the government, users in civil society, citizens and services (Nabatchi, Steen, Sicilia \& Brand, 2016). There are also those who argue that it creates public value: it has instrumental value for organizations in terms of improving efficiency, effectiveness and innovation (Osborne, Radnor \& Nasi, 2013); instrumental value for citizens in terms of satisfaction and training (Sancino, 2016); social capital (Jakobsen, 2013); and the presentation of accounts (Ostrom, 1996).

Nabatchi et al. (2017) affirm that co-production involves two types of participants: (1) estate agents who are (direct or indirect) agents of the government in a professional capacity (or in other words, the "regular producers") and (2) actors who are performing public service voluntarily as citizens, customers and/or consumers (or in other words, the "citizen producers"). Thus, in co-production estate agents are always present in a direct or indirect manner. Citizen producers, meanwhile, can participate in an individual or collective manner.

According to Osborne, Radnor and Strokosch (2016), the importance of co-production is derived not from its role in contributing to the impact and effectiveness of public services, but also its role in the well-being which results from this activity and its potential to facilitate the evolution of individual and collective capacities in responding in an independent manner to the social needs of the future (co-creation). This co-creation of value is fundamental for public services which are capable of verifying 
a citizen's contribution in a broader sense which is viable and effective for society, now and in the future. This is at the heart of the development of sustainable public services in the $21^{\text {st }}$ century.

Next, we will present Box 1, which displays the dimensions to facilitate the understanding of the NPG process. We do not seek to exhaust this subject here with the definition of the referred to constructs, but rather provide a broader vision of the aspects of NPG which can be analyzed.

Box 1

Dimensions of the Analysis of New Public Governance (NPG)

\begin{tabular}{|c|c|c|c|}
\hline Dimensions & Characteristics & Categories of Analysis & Authors \\
\hline \multirow{3}{*}{$\begin{array}{c}\text { BASIC } \\
\text { FUNDAMENTAL } \\
\text { ELEMENTS }\end{array}$} & \multirow{3}{*}{$\begin{array}{l}\text { Characterize the main concerns } \\
\text { of governance, serving as values } \\
\text { or main expected guidelines for } \\
\text { new public governance. }\end{array}$} & $\begin{array}{l}\text { Deliberative } \\
\text { Democracy }\end{array}$ & $\begin{array}{l}\text { Habermas (1995); } \\
\text { Dryzek (2010). }\end{array}$ \\
\hline & & Public Value & $\begin{array}{c}\text { Bozeman (2007), } \\
\text { Moore (1995). }\end{array}$ \\
\hline & & Co-production & $\begin{array}{l}\text { Ostrom (1972); } \\
\text { Nabatchi et al. (2017); } \\
\text { Alford (2009); } \\
\text { Osborne et al. (2016). }\end{array}$ \\
\hline \multirow{3}{*}{ STRUCTURE } & \multirow{3}{*}{$\begin{array}{l}\text { Consists of assuring that public } \\
\text { organizations, or the various } \\
\text { institutional and managerial } \\
\text { systems which integrate public } \\
\text { administration in a joint and } \\
\text { interactive manner, obtain the } \\
\text { desired results. }\end{array}$} & Shift in Power & $\begin{array}{c}\text { Pierre and Peters (2010); } \\
\text { Jessop (1993). }\end{array}$ \\
\hline & & Networks & $\begin{array}{c}\text { Rhodes (1997); } \\
\text { Provan and Kenis (2008). }\end{array}$ \\
\hline & & Coordination & $\begin{array}{c}\text { Bass (1985); } \\
\text { Bryson and Crosby (1992). }\end{array}$ \\
\hline \multirow[b]{2}{*}{ PROCESSESS } & \multirow{2}{*}{$\begin{array}{l}\text { Group of measures taken } \\
\text { to evaluate, monitor and } \\
\text { communicate the results of } \\
\text { created and implemented public } \\
\text { policies. Makes a judgment of } \\
\text { their value or merit considering } \\
\text { their relevance to the adopted } \\
\text { objectives and strategies. }\end{array}$} & $\begin{array}{l}\text { Efficiency and } \\
\text { Effectiveness }\end{array}$ & $\begin{array}{l}\text { Ridley and Simon (1937); } \\
\text { Christensen and Lægreid } \\
\text { (2011). }\end{array}$ \\
\hline & & Accountability & $\begin{array}{l}\text { Skelcher and Smith (2015); } \\
\text { R. B. Denhardt and J. V. } \\
\text { Denhardt (2003); } \\
\text { Christensen and Lægreid } \\
\text { (2007). }\end{array}$ \\
\hline
\end{tabular}

Source: Elaborated by the authors.

Now that we understand the basic fundamentals which support NPG, we will examine its structure. According to Dias (2012), NPG may be structured based on two main perspectives: a structuralist approach, given that these interactions are represented in various designs of structure and reality, and as a dynamic process of cooperation, given the considerable presence of interactivity. These perspectives are in line with the visions of Osborne (2010) and Wiesel and Modell (2014), who argue that NPG does not break away from the previous models of public administration, but rather improves upon them with the introduction of basic fundamentals for their analysis. In this way, it is a new vision of the concepts attributed by bureaucratic public administration and NPM, with characteristics of democracy, co-production and public value.

To Jessop (1993), from the structural point of view, we can analyze the following points: the shift of power, networks and coordination. In relation to the shift of power, we have identified three directions in which this shift can occur: a) downwarda shift of power from the central political system to regional and local systems; b) upward - a shift of power upwards in the sense of transnational organizations - such as the European Union, and the World Trade Organization (WTO); and c) outward a shift of power to external institutions with appropriate discretionary power which act as an extension of the competence of the state (Pierre \& Peters, 2010).

If the downward, upward and outward movements are seen by some as a loss of power on the part of the state, Pierre and Peters (2010) tell us that this occurs because the state agrees to this given the complexity of current problems. In their understanding, this power is delegated in a conscious manner by the state, and this is why it does not correspond to a diminution of the importance of its role or its capacity to guarantee development. 
In NPG, according to Pierre and Peters (2010), the state also "authorizes" the shift of power and control, maintaining an institutional structure designed to guarantee that the formulation and implementation of public policies will be projected throughout the entire country. In other words, it will delegate the power in the sense that each location or region will develop but as part of a whole that will remain under the competence and responsibility of the central government (Dias, 2012).

The formation of networks is another of the most striking characteristics of NPG. Networks have become more and more relevant, given that they are a way to administer policies and projects which involve complex problems, scarce resources, diverse actors and the interaction of public and private agents. Even though networks are conceived of in various ways, most of the definitions have certain characteristics in common: they are characterized by complex political problems which cannot be resolved by a single actor, and demand collective action from various actors (Koppenjan \& Klijn, 2004); there is a relatively high interdependency among the actors, because the resources necessary to resolve problems belong to different actors (Hanf \& Scharpf, 1978); these interdependencies cause a high degree of strategic complexity and an unpredictable course of interactions (Sørensen \& Torfing, 2007), and since actions of one actor affect the interests and strategies of other actors, network interactions have shown some durability over time (Agranoff \& McGuire, 2003).

Rhodes (1997) describes how networks can be characterized as degrees of stability in relation to the amplitude of the network and a greater or lesser horizontalization of the articulation. It adapts a structure by Marsh and Rhodes (1992) which distinguishes the size of the network based on its number of members, the types of interests that members bring to the network, the frequency of their interactions, the continuity and existence of a consensus among them, and the distribution of resources within the network and among the participating actors.

In relation to the coordination of networks, Souza and Hollanda (2019) emphasize that it rarely occurs in a spontaneous manner. When it is informal, it is subject to low effectiveness and durability, and effective coordination is required to structure and orient it in keeping with the objectives of the state (Provan \& Kenis, 2008). Thus, "coordinated governments" are essential to concentrate on sharing information and in order to share forces among all those involved in solving problems.

The structure of NPG networks leads to the development of a multilayered system of shared sovereignty. This development highlights deficiencies in traditional theories of democracy. According to Koliba, Meek and Zia (2010), democracy has to be promoted within a political system based on shared sovereignty, determined as the competence to make decisions and should be divided not within a predetermined political entity, but between relatively autonomous political units of social governance. In other words, they need to construct guidelines that will direct forces to dynamically construct "people" in concrete decision-making processes.

Various authors (Kelly \& Muers, 2002; Moore, 1995; Stoker, 2003) argue that in order to make NPG effective, public agents need to seek to act as what Ramadass, Sambasivan and Xavier (2018) denote as transformational leaders. It should be emphasized that transformational leaders exert their influence essentially through governance networks. Thus, to create public value, public agents should assume the responsibility to coordinate networks during their search.

To Bass (1985), the characteristics of a transformational leader which are relevant to collaboration in the public sector are: a focus on important priorities and objectives; creating an ethical climate, given that the objective of collaboration in the public sector is to resolve social problems; promote strong collaboration; guarantee appropriate governance; and encourage partners to work for the common good and achieve the desired results.

The literature regarding leadership in the field of public administration tends to see it as mainly based on individual or collective interests. From this perspective, the role of the leadership of public agents facilitates the coordination of the actors involved in the governance process, mobilizing and reuniting their dispersed resources in the face of "resource dependency structures" (Rhodes, 1988). A complementarity of interests may thus arise in a relatively balanced structure of resource dependencies, which may generate significant contributions to resources within the context of a political issue already underway or a series of interconnected issues. 
To the extent that negotiations consolidate other factors such as confidence and cooperation, they can develop, given that the actors will perceive that the desertion of any area can lead to the development of cooperation in other areas. Leaders stimulate a true sense of purpose in members, as well as the collaboration to energize these members to achieve their objectives (Ramadass et al., 2018). In turn, network members provide greater value for governance and to other actors seeking to achieve targets in their collaboration (Konorti, 2012).

Another factor to obtain success in the elaboration, application and monitoring of governance which contributes to effective public policies is the point to point analysis of processes (Hernaus, Vuksic \& Štemberger, 2016). Silva (2020) notes that one cannot analyze efficiency without associating it with effectiveness, because optimizing public resources without offering good services or resolving social problems is incompatible with the values defined in a democracy. Moreover, the tools used to analyze processes are emphasized in the NPM perspective, with the evaluation of efficiency, effectiveness and accountability (Sant'Anna et al., 2019; Silva, 2020). However, these tools/constructs are expanded in the NPG vision, because in addition to including economic results, or in other words, just the logic of analysis, it seeks a conciliation with social and democratic results. To NPG, you can have the best utilization of resources in terms of efficacy as well as effectiveness. Considering the way in which deliberations and decisions are made, guaranteeing the process's legitimacy, and considering the complementarity of the resources among the actors involved and the presentation of accounts, it is possible for public policies to be more effective.

One of the great advances that NPG offers in relation to the bureaucratic model and NPM is society's point of view to analyze the results of public administration. While the bureaucratic model focuses almost exclusively on efficiency, and is not concerned with results (effectiveness), NPM is a movement focused on results, but these results, as portrayed in the literature, are more related to management results, as if by being economically effective, they will be democratically effective (Christensen \& Lægreid, 2011; Ter Bogt, 2008). In addition, studies show that NPM encourages the proliferation of overlapping between different public entities, which has led to an increase in costs and a reduction in the efficiency of the public sector (Diefenbach, 2009; Rhodes, 1996).

For NPG, the assumption made in the evaluation of the results is different. The evaluation of the results from this perspective should be seen as a process oriented by judging the valuation and merits of governmental policy initiatives, whose results are capable of expressing social conflicts as well as conciliations developed in different contexts and institutions, and are expressed by the aggregate value to society. NPG contains the idea of public value, whose preoccupation goes beyond being economically efficient. It seeks socially desired ends through an incentive to participation in democratic and deliberative environments. Thus, in NPG, efficiency has political, democratic and inclusive connotations which are added to the supposition of administrative efficiency.

The last dimension of NPG is accountability. According to Campos (1990, p. 37), accountability is characterized as representing "[...] the objective responsibility of a person or organization to be answerable to other people or organizations". In treating accountability in NPG, to Sant'Anna et al. (2019), the state is called upon to recognize the values and interests of citizens, who in turn evaluate public policies exercising their capacity to pressure the government to correct its actions. This accountability, which they term multifaceted, should be part of a formal agreement between the interested parties in which there are clear definitions of roles, responsibilities and mechanisms of execution and responsibility.

Sinclair (1995) defines a broader definition of accountability in the public sector which goes beyond the scope of financial dimensions, including democratic, managerial, bureaucratic, professional and personal responsibility. In addition, the author envisions the presenting of accounts as multiple and fragmented, or in other words, accountability demands a commitment to make other types of presentations of accounts. In addition, he suggests that accountability is being constructed continually.

The appearance of NPG has changed policy and administrative coordination, as well as the types of leverage over influence and information which may have existed before (Christensen \& Lægreid, 2007). This greater complexity of accountability systems seeks to make processes more transparent (Dickinson \& Glasby, 2010), which frequently results in hybrid forms of accountability arrangements (Bracci, 2014). The work of Skelcher and Smith (2015) begins by exploring these alternative forms of hybridism, employing the concept of institutional logic to clarify mixed institutional values and argue that hybridism within this context emerges from a plurality of rationalities at play in institutions. 
In sum, NPG makes it possible for state actions to be permeated by the objective of promoting the quality of relationships and processes, which would be the fruit of public administration with a pluralist focus (open to all). In this way, policy networks configure a new model situated between extreme regulation (Polanyi, 1980) and the market's self-regulation (Smith, 1983), in which social structural relations created by the governance model are based on consensus and cooperation in the pursuit of long-term objectives in coordinated networks, and the evaluation of the results.

\section{CONCLUSION}

Given the complexity of current problems, the state has become more and more unable to resolve them on its own. The bureaucratic labyrinth in many cases impedes a more flexible and agile articulation in terms of the rapid resolution of problems.

States need to seek alternatives together with civil society, with specific competencies capable of producing better results for society as a whole. But inviting civil society to a public debate implies a series of problems that have not been well understood until now. For example, how can one evaluate the legitimacy of social actors in the definition of public policies? How can we verify whether public policies that are to be implemented are responsive? How can we understand the processes of deliberative democracy? What are the most important types of leadership for the conducting of policy deliberations? What are the main types of conflicts, participations and motivations of actors? How are governance structures formed? Even though the NPG offers a proposal of a citizen-oriented and participative society, there are few studies of the way to implement it.

One thing to point out is that one should not seek to find the best way to do things here. NPG requires an understanding of the environment where it is being proposed, the society's cultural values, the motivations of the participating actors, and the capacities and competencies of these actors, and guarantees the maximum legitimacy of its actions. These are quite complex challenges, but we are not trying to find the "best" NPG here. This idea is rejected given the needs and degree of evolution of each society and state, as well as the difficulty of resolving each problem. In this manner, the formats of public governance within the same society and by the same government can even be different.

This work has sought to present a discussion of, and the need to think about and understand NPG, as well as demonstrate its dimensions to facilitate the understanding of it. It thus seeks to advance this subject, emphasizing that the NPG model does not imply the exclusion of previous administrative models. Its emphasis is on the construction of a more legitimate and democratic model.

This article opens avenues to study various gaps in the literature. Each mentioned dimension deserves to be better structured in a manner that will enable public managers to execute NPG. For example, the construction of the term accountability in the NPG model requires a procedural approach, broadly studied in the Brazilian literature (Peixe, Rosa \& Passos, 2018) widely diffused by NPM, as well as a moral approach which is exclusive to NPG. There appear to be no doubts that the maintenance and improvement of democracy need to be based on the predisposition to have a closer relationship between the state and society, due to demands for a greater degree of accountability on the part of the state in terms of society, and the operationalization of control over governmental actions.

Finally, we would like to emphasize that studies point out the need to change the conception of government and the applied model of public administration to a center of ethical relations and obligations, based on the commitment to create a better world with meaning. Put another way, the literature has pointed out the emergence of a different way to govern and not necessarily a new model of government. This demands a broader vision which considers dimensions which have not been adequately contemplated by the traditional literature, highlighting the importance of democratic government, the focus on the public interest, and the role of the citizen, with the goal being the effective co-production of social values which should be publicly defined. It is a great challenge. 


\section{REFERENCES}

Agranoff, R., \& McGuire, M. (2003). Collaborative Public Management: New strategies for local governments. Washington, DC: Georgetown University Press.

Alford, J., \& Hughes, O. (2008). Public Value Pragmatism as the Next Phase of Public Management. The American Review of Public Administration, 38(2), 130-148.

Amamoto, A. F. S., Pereira, J. R., \& Alcântara, V. C. (2020). Remunicipalização e Coprodução do Bem Público: Perspectivas de Gestão dos Serviços de Água e Saneamento. Cadernos Gestão Pública e Cidadania, 25(81), 1-20.

Bass, B. M. (1985). Leadership and performance. New York, NY: Free Press.

Bingham, L. B., Nabatchi, T., \& O'Leary, R. (2005). The New Governance: Practices and Processes for Stakeholder and Citizen Participation in the Work of Government. Public Administration Review, 65(5), 547-558.

Bohman, J. (1996). Public Deliberation: Pluralism, Complexity and Democracy. Cambridge, MA: MIT Press.

Bozeman, B. (2007). Public Values and Public Interest: Counterbalancing Economic Individualism. Washington, DC: Georgetown University Press.

Bracci, E. (2014). Accountability and governance in social care: The impact of personalisation. Qualitative Research in Accounting \& Management, 11(2), 111-128.

Bryson, J. M., Crosby, B. C., \& Bloomberg, L. (2014). Public Value Governance: Moving Beyond Traditional Public Administration and the New Public Management. Public Administration Review, 68, 445-456.

Campos, A. M. (1990). Accountability: Quando poderemos traduzi-la para o português? Revista da Administração Pública, 24(2), 30-50.

Carneiro, R., \& Menicucci, T. M. G. (2011, December). Gestão pública no século XXI: as reformas pendentes. Textos para Discussão, 1686, 1-76.

Christensen, T., \& Lægreid, P. (2007). The Whole-of-Government Approach to Public Sector Reform. Public Administration Review, 67(6), 1059-1066.

Christensen, T., \& Lægreid, P. (2011). Complexity and Hybrid Public Administration - Theoretical and Empirical Challenges. Public Organization Review, 11, 407-423.

Dagnino, E., Oliveira, A. J., \& Panfichi, A. (2006). Para uma outra leitura da disputa pela construção democrática na América Latina. In E. Dagnino, A. J. Oliveira, \& A. Panfichi (Orgs.), A disputa pela construção democrática na América Latina. São Paulo, SP: Paz e Terra.

Davis, P., \& West, K. (2009). What Do Public Values Mean for Public Action? Putting Public Values in Their Plural Place. American Review of Public Administration, 39(6), 602-618.

Denhardt, R. B., \& Denhardt, J. V. (2003). The New Public Service: serving, not steering. New York, NY: M. E. Sharp.

Dias, T. (2012). Governança Pública: uma concepção teóricoanalítica aplicada no governo do Estado de Santa Catarina a partir da implantação das Secretarias de Desenvolvimento Regional (Tese de Doutorado). Universidade Federal de Santa Catarina, Florianópolis, SC.
Dickinson, H., \& Glasby, J. (2010). Why partnership work doesn't work': pitfalls, problems, and possibilities in English health and social care. Public Management Review, 12, 811-828.

Diefenbach, T. (2009). New public management in public sector organizations: the dark side of managerialistic "en lightenment". Public Administration, 87(4), 892-909.

Dryzek, J. (2010). Foundations and frontiers of deliberative governance. Oxford, UK: Oxford University Press.

Dunston, R., Lee, A., Boud, D., Brodie, P., \& Chiarella, M. (2009). Co-Production and Health System Reform - From Re-Imagining to Re-Making. Australian Journal of Public Administration, 68(1), 39-52.

Faria, C. F. (2000). Democracia deliberativa: Habermas, Cohen e Bohman. Revista Lua Nova, 50, 47-68.

Habermas, J. (1995). Três modelos normativos de democracia. Revista Lua Nova, 36, 39-53.

Hanf, K. I., \& Scharpf, F. W. (1978). Interorganizational Policy Making: Limits to coordination and central control. London, UK: Sage.

Head, B. W., \& Alford, J. (2015). Wicked Problems: Implications for Public Policy and Management. Administration and Society, 47(6), 711-739.

Hernaus, T., Vuksic, V. B., \& Štemberger, M. I. (2016). How to go from strategy to results? Institutionalising BPM governance within organisations. Business Process Management Journal, 22(1), 173-195.

Hufty, M. (2010). Gobernanza en salud pública: hacia un marco analítico. Revista de Salud Pública, 12(1), 39-61.

Jakobsen, M. (2013). Can Government Initiatives Increase Citizen Coproduction? Results of a Randomized Field Experiment. Journal of Public Administration Research and Theory, 23(1), 27-54.

Jessop, B. (1993). Towards a Schumpeterian Workfare State? Preliminary Remarks on post-Fordist Political Economy. Studies in Political Economy, 40, 7-40.

Jørgensen, T. B., \& Bozeman, B. (2007). Public Values: An Inventory. Administration \& Society, 39(3), 354-381.

Kalambokidis, L. (2014). Creating Public Value with Tax and Spending Policies: The View from Public Economics. Public Administration Review, 74(4), 519-526.

Kelly, G., \& Muers, S. (2002). Creating public value. An analytical framework for public service reform. London, UK: Cabinet Office Strategy Unit.

Kissler, L, \&; Heidemann, F. G. (2006). Governança Pública: novo modelo regulatório para as relações entre Estado, mercado e sociedade? Revista de Administração Pública, 40(3), 479-499.

Koliba, C., Meek, J., \& Zia, A. (2010). Governance Networks in Public Administration and Public Policy. Boca Raton, FL: CRC Press/Taylor \& Francis.

Konorti, E. (2012). The 3D transformational leadership model. The Journal of American Business Review, 1(1), 165-175. 
Koppenjan, J. F. M., \& Klijn, E. H. (2004). Managing Uncertainties in Networks. A network approach to problem solving and decision making. London, UK: Routledge.

Lynn, L. E., Jr., \& Malinowska, A. (2018). How are Patterns of Public Governance Changing in the US and the EU? It's Complicated. Journal of Comparative Policy Analysis: Research and Practice, 20(1), 36-55.

Marsh, D., \& Rhodes, R. A. W. (1992). Policy Networks in British Government. Oxford, UK: Clarendon Press.

Moore, M. (1995). Creating public value: Strategic management in government. Cambridge, MA: Harvard University Press.

Nabatchi, T., Sancino, A., \& Sicilia, M. (2017). Varieties of participation in public services: The who, when, and what of coproduction. Public Administration Review, 77(5), 766 -776.

Nabatchi, T., Steen, T., Sicilia, M., \& Brand, D. (2016). Understanding the Diversity of Coproduction: Introduction to the IJPA Special Issue on Coproduction. International Journal of Public Administration, 39(13), 1001-1005.

Osborne, S. P. (2006). The New Public Governance. Public Management Review, 3, 377-387.

Osborne, S. P. (2010). The new public governance: emerging perspectives on the theory and practice of public governance. Abingdon, UK: Routledge.

Osborne, S. P., Radnor, Z., \& Nasi, G. (2013). A New Theory of Public Service Management: Towards a (Public) Service-Dominant Approach. American Review of Public Administration, 43(2), 135-158.

Osborne, S. P., Radnor, Z., \& Strokosch, K. (2016). Co-Production and the Co-Creation of Value in Public Services: A Suitable Case for Treatment? Public Management Review, 18(5), 639-653.

Osborne, S. P., \& Strokosch, K. (2013). It Takes Two to Tango? Understanding the Co-Production of Public Services by Integrating the Services Management and Public Administration Perspectives. British Journal of Management, 24, 31-47.

Ostrom, E. (1972). Metropolitan Reform: Propositions Derived from Two Traditions. Social Science Quarterly, 53(3), 474-493.

Ostrom, E. (1996). Crossing the great divide: coproduction, synergy, and development. World Development, 24(6), 1073-1087.

Paula, A. P. P. (2005). Por uma nova gestão pública: limites e potencialidades da experiência contemporânea. Rio de Janeiro, RJ: Editora FGV.

Peixe, B. C. S., Rosa, C. Filho, \& Passos, G. A. (2018). Governança Pública e Accountability: Uma Análise Bibliométrica das Publicações Científicas Nacionais e Internacionais. Revista Contemporânea de Contabilidade, 15(36), 77-96.

Peters, B. G., \& Pierre, J. (1998). Governance Without Government? Rethinking Public Administration. Journal of Public Administration Research and Theory, 8, 223-224.

Pierre, J., \& Peters, B. G. (2010). Governance, Politics and the State. Houndmills, Basingstoke: MacMillan Press, 2010.

Polanyi, K. (1980). A Grande Transformação: as origens da nossa época. Rio de Janeiro, RJ: Campus.

Provan, K. G., \& Kenis, P. (2008). Modes of network governance: structure, management, and effectiveness, Journal of Public Administration Research and Theory, 18(2), 229-252.
Radnor, Z., Osborne, S., \& Glennonln, R. (1996). Public management theory. In C. Ansell, \& J. Torfing (Eds.), Handbook on theories of governance (pp. 46-60). Cheltenham, UK: Edward Elgar Publishing.

Ramadass, S. D., Sambasivan, M., \& Xavier, J. A. (2018). Collaboration outcomes in a public sector: impact of governance, leadership, interdependence and relational capital. Journal of Management \& Governance, 22(3), 749-771.

Rhodes, R. A. W. (1988). Beyond Westminster and Whitehall. London, UK: Unwin Hyman.

Rhodes, R. A. W. (1996). The new governance: governing without government. Political Studies, XLIV, 652-667.

Rhodes, R. A.W. (1997). Understanding Governance. Buckingham, UK: Open University Press.

Sancino, A. (2016). The Meta Coproduction of Community Outcomes: Towards a Citizens' Capabilities Approach. Voluntas: International Journal of Voluntary and Nonprofit Organizations, 27(1), 409-424.

Sant'Anna, L. T., Alcântara, V. C., Pereira, J. R., Cappelle, M. C. A., \& Tonelli, D. F. (2019). Aproximações entre Governança Colaborativa e Ação Comunicativa: Uma Proposta Analítica de Estudo. Revista de Administração Pública, 53(5), 821-837.

Silva, R. R., Neto, Reis, T. R., \&Ribeiro, A. L. (2020). Perfil da Gestão Municipal no Estado do Pará: Um Olhar a Partir do Índice de Efetividade. Contabilidade, Gestão e Governança, 23(1), 93-106.

Sinclair, A. (1995). The Chameleon of Accountability: Forms and Discourses. Accounting Organisations and Society, 20(2), 219-237.

Skelcher, C., \& Smith, S. R. (2015). Theorizing hybridity. Public Administration, 93(2), 433-448.

Smith, A. (1983). Riqueza das Nações: Investigação Sobre sua Natureza e suas Causas. São Paulo, SP: Abril Cultural.

Sørensen, E., \& Torfing, J. (2007). Theories of Democratic Network Governance. London, UK: Palgrave Macmillan.

Sorrentino, M., De Marco, M., \& Rossignoli, C. (2016). Health care co-production: Co-creation of value in flexible boundary spheres. In: T. Borangiu, M. Dragoicea, \& H. Nóvoa (Eds.), Exploring Services Science: 7th International Conference (pp. 649-659). Bucharest, Romania: Springer.

Sorrentino, M., Sicilia, M., \& Howlett, M. (2018). Understanding co-production as a new public governance tool. Policy and Society, 37(3), 277-293.

Stoker, G. (2003). Public Value Management (PVM): A new resolution of the democracy/efficiency tradeoff. Manchester, UK: Institute for Political and Economic Governance.

Ter Bogt, H. J. (2008). Recent and future management changes in local government: Continuing focus on rationality and efficiency? Financial Accountability \& Management, 24(31), 31-57.

Wallace, M., \& Tomlinson, M. (2010). Contextualizing leader dynamics: How public service leaders endeavour to build influence. Leadership, 6(1), 21-45.

Wiesel, F., \& Modell, S. (2014). From New Public Management to New Public Governance? Hybridization and Implications for Public Sector Consumerism. Financial Accountability and Management, 30(2), 75-205. 
Breno Augusto Diniz Pereira

ORCID: https://orcid.org/0000-0001-7387-5033

Post-Doctorate from the Center of Graduate Administration Research (CEPEAD) at the Federal University of Minas Gerais (UFMG); Associate Professor at the Federal University of Santa Maria (UFSM). E-mail: brenodpereira@gmail.com

Ivan Beck Ckagnazaroff

ORCID: https://orcid.org/0000-0002-8179-269X

Ph.D. from Aston Business School, Aston University; Full Professor in the Department of Administrative Sciences and the Center of Graduate Administration Research (CEPEAD) at the Federal University of Minas Gerais (UFMG). E-mail: ivanbeck00@gmail.com 